\title{
DILLIMİZE GIREŃLER
}

\section{Prof. Dr. Cemal MIHÇıOĞLU*}

Türk dili, özel göreçlerle yayaçların olağanüstü bir yaygınlık kazandığı 1992 yılında, yabancı, özellikle Ingilizce sözcüklerin yogun saldırısına uğradı. Bu saldın öylesine bir genişlik kazandı ki, eskiden dil konularında tutucu, tepkisiz davrananlar bile artık seslerini yükselımek durumunda kaldılar. Türk diline gönül verenleri çausı alında toplayan Türk Dil Kurumunun 12 Eylül 1980 eyleminden sonra bir devlet dairesine dönüştürülerek Türk đilinin bütünlügünün korunması dilevine inanmayanlara ya da devleti ele geçirenlerin bildikleri görüşlcrine karşı çıkmak yürekliliginini gösteremeyenlerin eline bırakılan Türkçenin savunulması konusunda örgütlü bir çaba boşluğu yarattı. Saldırı bütün hızıyla sürdü. Bir kamu kuruluşu olan TRT"nin göreç yayınlannda çingene ağzzyla konuşan oyuncular bile "a be yes, a be no, sugar çocuk" gibi sözlerle Türkçeye Ingilizce sözcükler sokuşturma yarışına katıldılar. Amerikan öykünmeciliłinin en gülünç ömckleriyle sık sık karşılaşıld.

Bu durum karşısında Türk dilinin savunulması konusu bireysel çabalara kalıyordu. Geçmiş̧e Türk Dil Kurumu içinde Türkçeyi batı kaynakh sözcüklerden arındırma çabalarına katılmış bir kimse olarak bize de bir görev düşıügünü düşündük. Gơzümüzü, kulağımızı açık tutarak toplu iletişim araçlarında geçen Ingilizce sözcükleri saptamaya, bunlara karşılıklar önermeye çalıştık. Kamuoyuna duyurulmayan bu tür çalışmalar kuşkusuz bir anlam taşıyamazdı. Yeni kimliģiyle Türk Dil Kurumu yayınlanının bơylece aradan çıkması karşısında ulaşabildiģimiz üniversite yayınlanna yönelmek durumunda kaldık. Üniversitelerde ụ̈ ayda bir çıması gereken dergilerin ya da yıllıkların yayımlanmasında bir yıla yaklaşan, dahası onu aşan gecikmeler bu çalışmaların güncelliģine gölge düşürmekle birlikte elimizdcki bu tek yolla yetinmek zorunda kaldık.

Bu satırların yazıldı̆̆ı sırada baskı aşamasınida bulunan dil konularıyla ilgili iki yazımız daha vardır. Ankara Üniversitesi Siyasal Bilgiler Fakültesi Dergisinin Ekim 1992 sayısında çıkacak olan "Türk Dilinin Savunulması" başlıklı yazıda çoğu son dönemlerde dilimizde kullanılmaya başlayan batı kaynaklı sözcüklere gerekçeli açıklamalarıyla birlikte karşılıklar önerilmiş, ikincisi Ankara Üniversitesi Iletişim Fakültesinin 1992 yıllığında yayımlanacak olan "Türetip Önerdiğim Sözcükler" başlıklı

*A.U. Siyasal Bilgiler Fakülısi Oğrctim Uyesi 
yazıda sőzcük türetme ile ilgili ğözlemlerle düşüncelerimiz yanında, tümüne yakın bir bollümünü 1975 'ten bu yana türetliğimiz sőzcüklerin bir dizelgesi verilmiştir.

Bu yazıda ise çoğu dilimize yeni giren Ingilizce sőzcüklere gerekçeli açıklamalan ile birlikte Türkçe karşllıklar onnerdik. Bütün bu önerilerimizin kamuoyunda olumlu yankalar bulmasinı dilerim.

\section{ANONS - BILDIRME, DUYURMA, SÖYLEME}

Fransizca annoncer eylemi Latince annuntiare'den gelir. $O$ da nuntius (haberci) sőzcügüünden türemiştir. Annoncer eyleminden gelen Fransızca annoncé adı o dildeki anons soylenişiyle Türkçeye de geçerek kullanım alanı bulmuştur. Sözcük goreç (tv) izlencelerinde ses sanatçılarını karşılarına alan sunucuların ellerindeki sesbüyütürleri onlara uzatarak "ilk sóyleyeceģiniz şarkıyı kendiniz anons eder misiniz" demeleri gibi durumlarda kullanılmaktadır. Sörcü̧̧ün buradaki anlamı Türkçede bildiģimiz bildirme, duyurma, söyleme'dir. Uygulamada bu sózcüklerin yeğlenmesi gerektigi kanısındayız.

Önek: Soyleyeceł̧iniz ikinci şarkıyı kendiniz bildirir misiniz, duyurur musunuz? Bundan sonra hangi şarkıyı sesiendirecegèinizi kendiniz söyler misiniz, duyurur musunuz?

CHECK - IN
CHECK - OUT CCIRDI IŞLEMI, - YŞLEMI, - YPMAK, GIRDILEMEK
YAPMAK, ÇIKTILAMAK

Ingilizce to check eylemi, çeşitli anlamları arasında, "denetlemek, incelemek, doğrulamak, işaret koymak" anlamlarına gelir. To check in eylemi ise bir otele girerken ya da bir uçağa binerken yazıımak anlamına gelir. Burada otele giris ya da uçağa binişte ayırtılan oda ya da yer kesin olarak kullanılmak üzere gerekli son işlem başlaulmakta, "girdi" işlemi yapılmaktadır. Oteldeki karşılama tezgâhında ad denetimi yapma, kimlik sorma ya da yazma gibi işler yapılıp müssteriye odası bildirilerek anahtanı verilmekte, valizini alan bir görevli eşliģinde odasının bulunduğu kata gönderilmektedir. Uçak alanında da belki haftalar önce saun alınmış bulunan bilet yolcu tarafından ilgili görevliye sunulmakta, üzerine gerekli son notlar düşülmekte, yolcunun yükü tartılıp varsa fazlası için gerekli ơdeme yapılmakta, yürüyen kuşakla uçağa doğru yöneltulmekte, yolcu uçał̆a biniş kartı verilip gerekli denetimler yapıldıktan sonra uçaģa giden koridor ya da salonlara yönlendirilmektedir. Burada da yapılan 'girdi işlemi' dir. Bu, sőzcügün ad olarak anlamıdır. To check-in eyleminin karşılığı ise girdi işlemi yapmak ya da girdilemek'tir.

Sơzcựün karşıtı olan to check-out ise yolcunun otel parasını ơdeyip eşyalanı alarak otelden çıkma işlemini kesinleştirmesi olayı ile bu işlemin yapılması anlamına gelir. Hava taşımacılığında da yolcunun iniş alanında uçaktan indikten sonra eşyasıını alarak ayrılması olayı ile bu eylemi anlatır. Bu sözcüge Türkçe karşılık olarak da çıkıs işlemi; çıktı işlemi yapmak, çıktılamak sőzcüklerini öneriyoruz.

Ornek: "Bavul ticareti" amacıyla Istanbul'a gelen Polonyalı turistlerin eşalarının çokluğu yüzünden girdi işleminin yapılması uzun sürdü. Uçak biletinizi girdilettiniz mi? Çıkı isslemini yaptınp otelden hemen ayrılmalıyız; kalkış saati yaklaşan uçą̆ımıza ancak yetişebiliriz. 


\section{DEFLASYON : INGINLIK}

Deflasyon karşlı̆̆ı̆ olarak türettiğim inginlik sőzựgünü ilk kez Kamu Yonetimi çevirisinin 1975 baskısında kullandım. Bu søzzcügü, yazdıł̆ım gerekçeyle birlikte, Türk Dil Kurumunda Tahsin Saraç'la benđen oluşan Bau Kaynaklı Sơzcüklere Karşlık Bulma Yarkurulunun 9 Mayıs 1975 günkü toplantısina gotürdüm. Orada benimsenen bu oneri, o dőnemde uygulanan yöntem uyarınca Yürütme Kuruluna gitmiş, ancak bize açıklanmayan, bilmediğimiz bir nedenle, "ilerde yeniden ele alinmak úzere" bir yana aynılmışt. Yarkurul'un çalışma dỉzeninde bir deģişiklik yapılıp ùye sayısı arturıldıktan sonra, 1977 yılında Yarkurul'a yeniden gottürdügüüm oneri benimsenerek aşağıdaki gerekşeli açıklama yazısı Türk Dili dergisinin Eylül 1978 sayısında yayımlandı:

Latincede "şişirmek" anlamına gelen flare eyleminin başına olumsuzluk anlatan de onekinin getirilmesiyle oluşturulan deflare "șiskinliğini indirmek" anlamına gelmektedir. Bu kökten türeyen Fransızcadaki déflation sözcựü Türķ̧eye de "deflasyon" söylemiyle geçmiştir. Deflasyon, piyasadaki para miktarıyla kredi oylumunun mallarla hizmetlerin oylumuna gore daha az olduğu durumlarda kendini gösteren ekonomik bir olaydur. Kök, anlam ठzellikleri g6z onulnde bulundurularak sözcuğe inginlik (para inginliği) karşılığı önerilmektedir.

Ornek: Inginlik dönemlerinde paranın değeri artığı için alacaklılar kazançlı, borçlular ise zararh çıkarlar. ald.

"Inginlik" sơzcứğĭ, Kurum'un 1978 yılında çıkan Ózleştirme Ķılavuzunda da yer

\section{DELEGE - YETKIMEN}

Fransızca délégué sơzcügü aynı soylenişle dilimize de geçerek "delege" biçimiyle kullanım yaygınlığı kazanmışur. Türkçe Sözlük delege için şu açıklamayı vermektedir: "Kendisine yetki verilerek bir yere ya da birinin katuna gonderilen kimse." Sözcage, anlam ozelligi goz onünde bulundurulup "Türkmen, kocaman" sరzcüklerinin yapısi orneksenerek "yetki" kökü ile "men" ekinden oluşturulan yetkimen karşılığı onerilmektedir. savundu.

Omek: Bu uluslararası toplantudaki Türk yetkimeni ülkesinin gơrişlerini başanyla

\section{DIREK(T) - DOGRU, DOSDOGRU}

Fransızca direct (okunuşu: direkt) sơzcügüü Latince dirigere (yð̋netmek) eyleminin geçmiş zaman ortacı olan directus'tan türemiştir. Anlamı "doğnu, dosdoğru"dur. Sơzcuk bu anlamda Türkşeye de geçerek halk arasinda kullanım yaygınlığı kazanmışur. Sözcük genellikle "direk" biçiminde sóylenmekte, anlam olarak belki de ormandan kesilmiş "düz, doğru" olan- direkle karışurılmaktadır. Sözcük dilimizde direkman (eki Fransızcada bulunmayan direct+ment) biçiminde de kullanılmaktadır. $\operatorname{Direk}(t)$ için dilimizdeki doğal karşılıklan olan doğru, dosdoğru sözcüklerinin kullanılması ónerilmektedir. Direkt sðzcügünün dilimize de geçen bir başka anlamı, bilindiģi gibi, "doğnudan, dolaysız"dır.

Ornek: Uçakıan inince dogrı (dosdogr ru) okula gitti. Aradığınız evi bulmak için doğru (dosdoğru) gidiniz, sağdan üçüncui sokała sapınız, solunuzdaki ikinci evdir. 


\section{ENFLASYON - ŞIŞKINLIK}

Enflasyon için türettiģim şişkinlik karşılı̆̆ını ilk kez Kamu Yönetimi adlı çeviri kitabımın 1975 baskısında kullandım. Sözcügü, daha geniş bir çevreye duyurabilmek amacıyla, gerckçeli bir açıklamayla birlikte Türk Dil Kurumundaki -Tahısin Saraç'la benden oluşan- Batı Kaynaklı Sözcüklere Karşılık Bulma Yarkurulunun 9 Mayıs 1975 günkü toplantısına götürdüm. Benimsenen bu öneri, yazdığım gerekçeli açıklamayla birlikte Yürütme Kuruluna gittiyse de "ilerde yeniden cle alınmak üzere" bir yana ayrıldı. Sơzcü̧üi 1977 yılında, çalışma düzeniyle bileşiminde deģişiklikler yapılan Yarkurul'a yeniden götürdüm. Benimsenen öneriyle ilgili aşağıdaki gerekçeli açıklama, Türk Dili dergisinin Eylül 1977 sayısında yayımlandı:

Latincede inflare (in+flare) "içine üfleyerek şişirmek" demektir. Bundan türeyen Fransızcadaki inflation sözcǚğu "enflasyon" söylemiyle dilimize de geçmiştii. Enflasyon, ekonomi biliminde, piyasadaki para miktarıyla kredi oylumunun mallarla hizmetlerin oylumuna oranla daha geni̧ olması anlamına gelmektedir. Kök, anlam özellikleri göz önünde bulundurularak enflasyon için şişkinlik (para şiskinliği) karşılığı önerilmektedir.

, Örnek: Şişkinlik dönemlerinde paranın değeri düştüğu için, borçlular kazançlı, alacaklılar zararlı çıkarlar.

Bu anlamda "şiskinlik" sözcügüne Kurum'un 1978'de çıkan Özleştirme Kılavuzunda da yer verildi.

Türk geçimsel yaşamının süreł̧en bir sorununa dönüşen enflasyon son yıllarda, özellikle 20 Ekim 1991 seçimlerinden sonra basında olsun yayın kuruluşlannda olsun çok tartı̧̧ıldı. Konuyu cle alan bir görę̧ (tv) izlencesinin başında köylüsüne kentlisine, kadınına erkeğine, yaşlısına gencine elindeki sesbüyütı̈rü uzatarak o Franşızca kökenli sőzcügü kullanıp "sizce enflasyon nedir?" sorusunu yönchıen izlence görevlisinin sergilediłgi görüntüyü çok yadırgatıcı bulmuşık. Bu tür tartışmalar sonunda ülkemizde "şişkinlik"in ana nedeninin başıa KIT açıkları olmak üzere kamu kesimi açıklarının para basılarak karşılanması oldugu, öbür nedenler arasında toplumsal güvenlik kuruluşları açıklarının, devletçe yurtış̧ın yapılan tarım ürünü satınalmalarından doğan açıkların, kent yönetimleri açıklarının yer aldıł̆ı artık'gencllikle bilinmektedir.

\section{FIGÜR - DEVINTI}

Fransızca figure (okunuşu: figür) sözcügü Latince figura (biçim) sözcü̈ünden gelir. Fransızcadan Ingilizccye de geçmiş bulunan sözcük, Fransızcadaki sőyleniş̧iyle Türkçcye de girerek yaygınlık kazanmıştır. Sözcügün resimle yontuculuktaki anlamı "biçim"dir. Burada onun danstaki anlamına bir karşılık onermek istiyoruz. Dansta figür, "bir devinimler küme ya da topluluğu" anlamına gelir. Bir başka deyişle, figür, bir dansı oluş̧uran, kendisi de daha az sayıdaki devinimden oluşan evre ya da birimlerdir. Görülüyor ki burada söz konusu olan eylem "devinmek"tir. Sözcüßge, "ağartı, döşenti, gögerti" sözcüklerinin yapısını örnckscycrek, eylem köklerinin sonuna getirilerek ad türetmekte kullanılan - $l l$, - $t i$ ckinden yararlanarak oluşırduğumuz devinti karşılığını öneriyoruz.

Örnek: Bu dansın çeşitli devintilerinden ancak belli başlılarını ögrenebildim. 


\section{GLOBAL - EVRENSEL GLOBALLESME - EVRENSELLEŞME}

Fransızcadan Ingilizceye de geçen globe (okunuşu: glob) (yer yuvarlağı, dünya) sözcügü Latince globus (yuvarlak, top) sözcügünden gelir. Globe adından türeyen global sözcügü bir bütün olarak dünya ile ilgili, dünya çapında demektir. Gerek global sözcügüu gerek onun ad biçimi olan globalleşme (globalization) sözcügü son iki üç yıl içinde dilimize de geçerek yaygınlık kazanmıştır. Özellikle basında Arapça küreye Türkçe -sel eki getirilerek oluşturulan "küresel"le karşılanan bu sözcügün aslında Türkçe bir karşılığı vardır. Nitekim "evrensel" sözcügünün anlamı Türkçe Sözlükte şöyle verilmektedir: 1 . Evrenle ilgili, 2. Tüm insanlığı ilgilendiren, âlemşümul, cihanşümul, üniversel, 3. Dünya ölçüsünde, dünya çapında. Sözcügün kâinatla ilgili demek olan ilk anlamı dışındaki anlamları dogrudan doğruya buradaki global'in karşılığıdır. Insanlar çok ileride dünya dışındaki kainatla bütünleşip oturma, iyelik ilişkisi kurma gibi daha yakın bağlantulara girmedikçe bu ilk anlamla öbürleri arasında bir karışma olması söz konusu değgildir. Bu duruma göre global'c evrensel, globalleşmeye evrenselleşme demek Arapça sözcüklerden Türkçe eklerle "Türkçe" sözcük üretmekten daha uygun bir yoldur.

Örnek: Çevre kirliliği evrensel bir sorundur. Türkiye'nin geçimsel ilişkileri evrenselleşmeye başlamışur.

\section{HELIKOPTER - DÖNERKANAT}

Fransızca hélicoptère, tepesinde uçmayı sağlayan bir pervanesi bulunan, dikey bir eksen çevresinde dönen bu pervanenin aşağıya dợru oluşturduğu hava akımının gücü ile dikey iniş kalkış yapabilen hava taşıtının adıdır. Kuyrugưnda bulunan küçük pervane ise aracı daha çok istenen yöne döndürmeye yarar. Yunanca helix, helico (helezon) ile pteros (kanat) öģelerinden oluşturulan sözcüğün kök anlamı "sarmalkanat"tır. Sözcügüün bu kök anlamı, aracın kalkış ya da iniş surasında kanat görevi yapan pervanenin sarmal bir çizgi çizcrek uçuyormuş izlenimini vermesinden ileri gelmiş olsa gerektir. Sözcük helikopter yazılışıyla Türkçeye de geçerek yerleşmişur. Helikopter sözcügüne, kanat yerine geçen pervanenin dönüşü ile kalkışa geçmekte, yer deģiştirmekte, inişe geçmekte olması özellił̧i göz önünde bulundurularak, "döner r" ile "kanat" sözcüklerinden oluşturulup sözcügün kök özelligłine de genellikle uygun düşen dönerkanat karşlığg önerilmektedir.

Ömek: Savaş dönerkanatları makineli tüfeklerle, toplarla, güdümlü mermilerle donatılabilmcktedir. 1964-75 Vietnam savaşında Amerikalılar 450'şer dönerkanattan oluşan bindirilmiş tümenler kullandılar

\section{HEMERALOPI - BOL IŞIK GÖRMEZLIĞI HEMERALOP - BOL IŞIK GORMIEZI \\ Bkz.: Niktalopi}

Dilimize Fransızcadan geçmiş olan hemeralopi sözcügü için bol ışık görmezliği karşılığını "niktalopi" için önerdił̧im "az ışık görmezliłi" ile birlikte 8 Haziran 1986 Pazar günü türectim. Bu konuda gerckli bilgilcrin bir bölümü "niktalopi" maddesinde verildiği için oraya bakınız.

Yunanca "hemera, gün + (nyktalops= gece ya da gündüz körlügü olan kişi'den) alops" öğclerinden oluşan hemeralops sözcügü daha sonra Latinceye geçmiş, 
Fransızcadaki "héméralopie" ile Ingilizcedeki "hemeralopia" sözcükleri de oradan kaynaklanmıştır. Ingilizce büyük Webster'de sözcügün hekimlikteki ilk anlamı "kişinin, seçik bir biçimde, acı çekmeden yalnız gece, az ışıkta ya da kapalı günlerde görebilmesi biçiminde kendini gösteren bir göz rahatsız.lığı" olarak verilmekte, ardından da sözcügün kanş̧ırılarak "nyctalopia" anlamında kullanıldığı belirtilmektedir. J.A.C. Brown'ın Pears Medical Encyclopaedia'sında "hemeralopia," "kişinin yarı aydınlıkıa tam gün ışığına göre daha iyi gördügü gündüzkörlü̈gü durumu" olarak tanımlanmaktadır.

Fransızca sózlüklerde -bu arada Robert'le Larousse'ta- "héméralopie" ile "nyctalopie"ye bunun tümüyle tersi bir anlam verilmektedir. Tahsin Saraç'in Fransızca Türkçe Büyük Sözlük'ünde de "héméralopie"nin Türkçe karşılığı "gece körlügüü olarak verilmiştir. Dr. Şefik Ibrahim Iş̧il'le Ali Ulvi Elöve'nin 1944-1948 yılları arasında TDK'ca bölük bőlük yayımlanan Türkçe Hekimlik Terimleri Üzerinde Bir Deneme adlı sőzlügünde de "héméralopie"nin Türkçesi "tavuk karası, tün görmezlił̧i" (Osmanlıcası "aşavet") olarak verilmektedir. Bu sözlükte terimin Almancasının "Nachtblindheit" olarak verilmiş bulunmasından, Almancada da durumun Fransızcadaki gibi oldugu sonucu çıkmaktadır. Dr. Süreyya Ülker'in Hekimlik Terimleri Sözlügünde "hemeralopia" için, 1. yarasa gözlülük, eşanlamlı sözcükler olarak da güngörmezlik, gün sokurluğu, 2. nyctalopia karşılıkları verilmiştir. Ingilizce hekimlik terimleri sözlüklerinde, "hemeralopia"nın karşısında ayrıca eşanlamlı bir karşılık olarak "dayblindness" (gündüz körlügüi) sözcüğ̈̈ne de yer verilmektedir.

Kanımca bu sözcükle ilgili karışıklık, özünde Yunanca "nyktalops" sözcügündeki iki anlamlılıktan kaynaklanmakta, dilimize önce Fransızcadan "héméralopie," sonra da Ingilizceden "hemeralopia" sözcügünün girmiş olması bu karışıklığı daha da artırmış bulunmaktadır.

"Gündüzkörlügü" gibi bir karşılığın da dợru olmayacağı düşüncesindeyim. Çünkü bu rahatsızlığ olanlar gündüz görcbilmekte, ancak ışığı çok bol, çok parlak olduğu durumlarda görme güçlügü çckmektedirler. Dolayısıyla bizim önerdiğimiz "bol ışık görmezliği" her türlü karışıklığı önleyebilecek bir karşılık olarak görünmektedir. Bu durumda Fransızca ile Ingilizcedcki "héméralope, hemeralope"un (okunuşu: hemeralop) Türkçedeki karşılı̆̆ da bol lşı görmezi olacaktır. Böylece, terime, gözü görmeyenlerin pek sevmedikleri Farsça kökenli "kör" sözcügü kullanılmadan uygun bir Türkçe karşılık bulunmuş olmakıadır.

\section{HIPER - AŞIRI}

Ingilizce ile Fransızca gibi bau dillerinde kullanılmakta olan hyper- öneki Yunanca olup başına geldiłi sözcüklere "aşırı, yukarı, dışında, üstünde" gibi anlamlar katar. Hipertansiyon aşırı kanbasıncı, hipertrofi aşırı irileşme, hiperenflasyon "aşırı şişkinlik" demektir. Hipermarket ise bclirli bir oylumu aşan süpermarket, "çok büyük -aşurı ölçüde büyük- besin satımevi" anlamına gelir. Sözcük dilimize de geçerek kullanım alanı bulmuştur. Hiper için dilimizdcki doğal karşılığı olan aşırı sözcügü önerilmektedir.

Örnek: Geçimsel işlerden sorumlu devlet bakanı, "şişkinliłgi umdugumuz düzeye indiremedik, ama aşır şişkinliği önledik" dedi. 


\section{IN.........OUT , IÇERI........ DIŞARI}

1992 yılında Amerikan Ingilizcesinin etkisiyle Türkçede olduğu gibi kullanılmaya başlayan Ingilizce belirteçlerden ikisi "in" ile "out"tur. Gerek basında, gerek göreç izlencelerinde yılın "in"leri ile "out"larından söz edilmekte, böylece yeni yıl içinde gözde olan ya da gözde olması umulan kavram ya da uygulamalar siralanı "in" denmekte, gözde olmayan ya da olması istenmeyenler sıralandıktan sonra "out" sözcügü kullanılmaktadır. Bu sözcüklerin dilimizdeki anlamları sırasıyla "içeri" ile "dışarı"dır. "In" ile "out" için, Türkçede doğal karışılıkları olan "içeri" ile "dışarı" sőzcükleri önerilmektedir.

Ömek: 1993 yılında kamu yaşamımızda aktöre dışı uygulamalar, yolsuzluklar dışarı, doğruluk, özveri içeri, eylemsizlik dıs̆arı, üstün çaba içeri.

\section{KABOTAJ - ULUSAL KIYI TAŞIMACILIĞI KIYI TAŞIMACILIĞI}

Fransızca cabotage sözcügü, o dildcki kabotaj okunuşuyla dilimize de girmiştir. Sözcügün anlạmı bir ülkenin kendi kıyılanındaki deniz tecimini kendi yurttaşları, özellikle de kendi bayrağını taşıyan gemiler için' sakı tutmak amacıyla bağışladığı ayrıcalıktır. Bizde kapitülasyonlar dolayısıyla yabancı uyruklu gemilere taninan bu ayrıcalık, 1923 yılında Lozan Antlaşmasıyla kaldırılarak Türk yurttaşlarına, Türk bayrağını taşıyan gemilere verilmiştir. Böylece ülkemiz kıyılarının bir yerinden bir başka yerine yolcu ya da yük taşıma hakkı yalnız Türk gemilerinde bulunmaktadır. Sözcüge, gerek anlam, gerek işlev özelliğine uygun düşen ulusal kıyı taşımacılığı, ya da kısaca kıyı taşımacılığı karşılığı önerilmektedir. Karşılığı birden çok sözcükten oluşması kanımızca bir sakınca oluşturmamakta, tersine, kavramın niteliğini açıkca ortaya koyarak onu ilk bakışıa açıklığa kavuşturmakta, böylece bir Türk için hiçbir anlam taşımayan, üstelik kökeni de açık olarak bilinmeyen yabancı bir sözcükten kurtulmamııı saglamaktadur.

Örnek: Bizde 1926 yılından bu yana 1 Temmuz Denizcilik-Ulusal Kıyı Tasımacıllığı. Bayramı olarak kutlanmaktadır.

\section{KONSANTRE - YOĞUNLAŞTIRILMIŞ}

Fransızca concentrer eylemi yoğunlaşurmak demektir. Bu eylemden türeyen concentré (okunuşu: konsantre) oradaki söylenişiyle dilimize geçerek kullanılmaya başlamışur. Bu sözcügün dilimizdcki anlamı yoğunlaştırılmış'ır. Sözcüğün bir de ad anlamı vardır ki Türkçesi özüt'tür. Konsantre sözcügünün önad karşlıł̆ olan yoğunlaştırılmışın sözcügün her anlamını doyurucu bir biçimde karşılayabileceği kanısindayız.

Örnck: Iki kutu vernel yerine bir kutu yogunlastırılmıs vernel kullanmak çevre kirliliģini bir ölçüde önler. Bu yoğunlaşırılmıs portakal suyunu içerken dört kau su ile karışurmak gerekir. 


\section{LEADING EDGE - ÖNÇIZGI}

Ingilizce leading edge sözüyle ilk kez 1984 Temmuzunda Didim Alunkum'da okuduğum ełgitim tasarlamasıyla ilgili bir yayında karşılaşıp uygun bir kanş̧ılık bulmak geregini duydum. Anakara'ya döndükten sonra bir sivil hayacıdan bu konuda ek bilgi aldım. Aradan uzun bir süre geçtikten sonra, 20 Kasım 1990 günü, "ekolayzer" sözcügü konusunda görüşüne başvurduğum Profesör Cahit Çıray'a havacılıkla da ilgilendigini oğrenmem üzerine, bu kavram üzerinde de sorular sordum. Ilk görüştügüm havacının - "leading edge" için kullanıldığını söylediği "firar hatu"nın kavramın karşıtı olan "trailing edge"in karşılığ oldugunu, ilkine "hücum hatu" dendigini ondan ögrendim. Kavramın aşağıdaki gerekçeli açıklamasinı ondan aldığım bilgilerin ışı̆ı̆ alunda kesinleştirdim.

Havacılıkta kullanılan leading edge sözünün Türkçede kullanılan eski bir karşlı̆̆ı bulunmakla birlikte, bu terime uygun bir gerçek Türkçe karşlığın bulunması yararlı olacaktır.

Ingilizcede to lead eylemi "götürmck, yol göstermek, yönetmek, başına geçip yol göstermek" gibi anlamlara gelir. Edge sözcüğ̈u ise "kenar" demektir. Leading edge, bir uçakta kanat, dümen gibi -içinde yol aldığı havanın üzerinde bir tepkimeye yol açması amacıyla tasarımlanmış- düz ya da eğimli bir yüzeyin ya da bir pervane kanadının en óndeki kenarı, çizgisi anlamındadır. Türkçede buna. Fransızca karşılı̆̆ı olan bord d'attaque'ın neredeyse sözcủgù sözcüğüne bir çevirisi olan "hücum kenarı" denmektedir. Biri Arapça, öbüru Farsça iki sözcükten oluşan bu eskimiş karşlık yerine, biz, terimin anlam özelliģine uygun düşen önçizgi karşılığın öneriyoruz. Ingilizeede anlam genişlemesi yoluyla genel dilde de "öncü, önde giden, direnci gögüsleyen" anlamlarında kullanılan leading edge sözù için çevirmenlerin Türkçede "önçizgi" sözünü kolaylıkla kullanabilecekleri de açıktır.

Leading edge teriminin karşıtı ise trailing edge'dir. Yine Ingilizcedeki to trail eylemi ise çeşitli anlamları arasında "sürüklemek, arkası sıra sürüklemek" gibi anlamlara gelir. Trailing edge, bir uçakta kanat, dümen gibi, havanın üzcrinde bir tepkimeye yol açması amacıyla tasarımlanmıs düz ya da eğimli bir yüzcyin ya da bir pervane kanádının en arkadaki kenarı ya da çizgisi" demektir. Türk havacılığında bunun için de, Fransızcadaki karşılığı bord de fuite'in bir çevirisi olan "firar hattı" sözü kullanılmaktadır. Ikisi de Arapça olan bu sözcükler yerine arţ̧zgi karşılı̆̆ını öneriyoruz.

Ornek: Nurullah Ataç, 1940'larla 1950'lerde dilde özleşme akımının önçizgisinde bulunan başlıca kişiydi.

MARS - 1. YÜRÜ (komut), 2. YÜRÜT (ad) MARŞ MARŞ - KOŞ KOŞ

Fransızca marcher eylemi (okunuşu: marşe) "yürümek" anlamına gelir. Bu sözcükten türeyen marche (ókunuşu: marş) oradaki söylenişiyle Türkçeye de geçerek yaygın bir kullanım alanı bulmuştur. Marş sözcügünün bize de geçen ilk anlamı, askerlikteki "yürü"dür. Anlaşılan XIX. yüzyılın başlarında Osmanlı ordusunu eģitmek üzere getirtilen Fransız subayları, kendi dillerinde "marş" demiş, bunun Türkçedeki bildiğimiz "yürü" anlamına geldiğini düşünemeyen o dönemdeki atalarımız bunu belki de çağdaş "fenn-i askerî"ye özgü bir terim gibi algılayarak olduğu gibi benimsemişlerdir. Sözcük dile öylesine yerleşmiştir ki bugüne de gin Türkçesini kullanmak kimsenin usuna gelmemiştir. Anadolu'nun dağından ovasından gelmiş Türk askerine Fransızca "yürü" deyip durmak en azından yadırgadıcıdır. Sözcügün askerlikıcki bu "yürüyüşe geçme komutu" anlamı için yürü karşılığını öncriyoruz. Yine askerlikte bir de mars mars komutu vardır. Bu komut, kural olarak 30 adıma dçgin olan kısa koşmalar için verilir. Bu 
koşmada silahın durumu ile birliğin düzeni bozulmaz. Bu komut daha uzun koşmalar için de verilebilir. Burada birliğin düzenine bakılmaksızın bülün güçle koşulur. Işlev özellił̧i . göz önünde bulundurularak, bunların ikisi için birden koş kos karşılığı önerilmektedir.

Sözcügün dilimize geçmiş ikinci anlamı da "askerin uygun adımda yürüyüşüne eşlik etmck üzere düzenlenmiş, belirli aralıklarla vurgulu, tarumlı, düzenli müzik parçası"dır. Sözcügün bu anlamı için, "anıt, yapıt, yakıt, umut" sözcüklerinin yaṕssını ömekseyip dilimizde eylem köklerine cklenerck ad türetmekte kullanılan - $t$ ekinden yararlanılarak yürüt karşılığını öncriyoruz. Arabalardaki marş için de yürüt karşılıł̆ını öneriyoruz.

Marş sözcügünün Türçedeki tümüyle yanlış bir kullanımı da "milli marş" sơzü içindeki yeridir. Çünkü ulusların sesel simgesi olan müzik parçalan "marş" değil, başka bir deyişle askerin uygun adımla yürüyüşüne elverişli değildir. Bildiğimize göre bunlara başka dillerde de marş denmez. Kullanilan sözcük, ömeğin Fransizcada hymne, Ingilizcede anthem'dir. Bunların ikisinin de anlamı "ilahi"dir. Gerçekte her ulusal "marş" bir "ezgi"dir (melodi). Ona belirli bir ezgi türünün adını verecek yerde kısaca "ulusal ezgi" demek en uygun çözüm olarak görünmektedir. Bu duruma göre milli marşa ulusal ezgi karşılığı önerilmektedir.

Örnek: En öndeki birlik komutanının yürü! komutuyla geçit töreni başlamış oldu. Alatürk, ölümünden kısa bir süre önce, Hatay'ın anayurda katılmasıyla ilgili olarak güneye yaptı̆ı gezinin sonunda Adana'da düzenlenen bir geçit töreninde, saglık durumu iyi olmadığından uzun süre ayaǩla durmakı güçlük çekmiş, o sırada verdiği kos kos!' komutuyla önünden geçmekte olan birliģin daha kısa sürede geçmesini saglamışt. "Ey vatan göz. yaşların dinsin yetiştik çünkü biz" dizesiyle tanınan Mülkiye Yürütünün sözlerini 1918 yenilgisini izleyen günlerde Mekteb-i Mülkiye ögrencilerinden Cemal Efendi (Yeşil) yazmış, bu sözleri okulun müzik ögretmeni Musa Süreyya Bey bestclemişti. Ulusal ezgimizin sözleri Mehmet Akif Ersoy'undur. 1924 yılında A. Rıfat Çagatay'ın yaptığı beste 1930 'da Zcki Üngör'ce değiştirilerek şimdiki biçimini almışır. Arabaya aulamasıyla yürüte basıp fırlaması bir oldu.

\section{MEDYA - TOPLU ILETIŞIM ARAÇLARI, TILAR}

Ingilizcede kullanılan Latince media (okunuşu: medya) (araçlar) sözcügü medium (araç) sözcü̈ünün çoğuludur. Sözcük, basın, yayaç (radyo), göreç (tv) gibi geniş yıł̆ıılara seslenen toplu iletişim araçlarına verilen "media of mass communication" ile "mass media" deyimleri içinde yaygın olarak kullanılmaktadır. O dilde tek başına "media" dendiğinde bu tür araçlar anlaşılmakta, başka bir deyişle "media" sözcügü bu deyimlerin kısaltılması gibi kullanılmaktadır. Sözcük oradaki medya okunuşuyla son yıllarda Türkçeye de geçerck yaygınlık kazanmışur. Bu deyimlerin dilimizdeki karşılığı toplu iletişim araçları olduguna görc medya yerine de o kullanılmalıdır. Bu. konuda Ingilizecde olłuğu gibi sözcük tulumlulựuna çok önem verenler için ise toplu'nun ilk yazacı olan t'ye iletişim'in il'i, araçları'nın ar'ı eklenerck oluşturulan tilar karşılığını öneriyoruz.

Hekimlik dilindcki media ise yine Latince medius (orta) sözcügünden türemiştir. Bir damar çcperinin "orta katman"ı anlamına gelmckıedir.

Örnek: Şişkinlik konusu toplu iletişim araçlarında enine boyuna taruşıldı. 


\section{MEGA - BÜYÜK ; BÜYÜKLERIN BÜYÜĞ̈̈}

Ingilizce, Fransızca gibi batı dillerinde kullanılmakta olan mega öneki Yunanca megas, megalou (büyük) sözcügünden gelir. Bu önek bir yandan önüne geldił̆i sözcüge büyük anlamını katmakta, bir yandan da fizikte milyon anlamına gelmektedir. Hekimlikte megakolon büyümüş kalınbağırsak, megakardiya büyümüş yürek ya da yürek büyümesi anlamına gelmektedir. Megavat bir milyon vat, megafarad ise bir milyon farad demektir. Sözcük aynı mega söylenişiyle Türkçeye de geçmiş, 1990'lı yılların başlarında özellikle bzzel göreçle (tv) yayaçların (radyo) yaygınlaşmasından sonra sırıtan bir Amerikan oykünmeciliģinin etkisiyle, daha çok "megastar" sözcügü içinde sık sık kullanılmaya başlamışur. Sözccügün buradaki doğru karşilı̆̆ı büyük oldựuna göre onun kullanılması uygun olur. Ancak sözcügün ahengine kendini kaptıran birçok yurtıaşımızın onu "büyüklerin büyügüu, en büyük, üstüne yok, doruklarda" gibi abartılı bir anlamda kullandıklan açıkur.

Örnek: Bu dinletide parçaları tümü birer büyük yıldız olarak nitelenen sanaţ̧ılar seslendirdiler.

\section{MOTIVE ETMEK - G ̈ÜDÜLEMEK, ÖZENDIRMEK, ISTEKLENDIRMEK}

Ingilizce to motivate eylemi motive adından türemiştir. Motive'in Türkçedeki karşılığı güdü, eski dilde saik'tir. Güdüler, insan davranışlarını etkileyen, onların itici gücü niteliģini taşıyan tinsel güçler, bir başka deyişle istekler, onların da altında yatan gereksinimlerdir. Güdü, bir gereksinimi giderme isteģi, eğilimi olarak tanımlanabilir. Bu bakımdan gụ̈düler bir çeşit tinsel gerilimler olarak da nitelendirilebilirler. Bu eylem, söylenişi bir ölçüde Fransızcalaşurılarak, motive etmek biçiminde dilimize de geçerek kimi çevrelerde kullanım alanı bulmuştur. Bu duruma göre motive etmenin tinbilimdcki terim anlamı güdülemek'tir. Işin aslına inilirse bir kimseyi bir işi yapmaya özendirmek, isteklendirmek'tir. Sözcük için bu karşllıklar öncrilmektedir. Fransızcada da motiver cylemi kullanılmakla birlikte daha .̧ok "gerckçesini belirtmek; gerektirmek, zorunlu kılmak, neden olmak; haklı göstermek" anlamlarında kullanilmaktadır.

Örnek: Çalı̧̧anlan güdülemenin (işe özendirmenin, isteklendirmenin) yollarından biri yönetime katılmalarını sağlamaktır.

\section{NIKTALOPI - AZ IŞIK GÖRMEZLIĞI NIKTALOP - AZ IŞIK GÖRMEZI \\ Bkz.: Hemeralopi}

Tıp ögrenimi görmekte olan oğlum, gecenin geç saatlerine dek bir arkadaşıyla birlikte çalışı̆̌ı 19 Mayıs 1986 günü odasından bana seslenerck "gece körlügüünün bilimsel adının ne olduğunu sordu. Birką̧ saniye düşündükten sonra anımsayıp "niktalopi" karşılığını verdim. Ertesi gün oğlumun "hemeralopi" sözcüğünün de e§̧ anlamda kullanıldığını söylemesi üzcrine iki tcrimi birlikte düşünmeye karar verip 8 Haziran 1986 Pazar günü niktalopi için az ışık görmezliği, hemeralopi için de bol ışı görmezliği karşılı̆̆ını türettim. Oł̧lum, karşılıktan çok açıklama niteliģi taşımalarına karşın, bunları beğendiğini söyledi. Daha sonra karşılıklardan kendisine söz 
ettiğim Emin Özdemir de, sağladıkları anlam açıklığı karşısında bunları çok olumlu bulduğunu belirtu.

Ancak, bu sonuca oldukça karışık olan durumu araşurip bir açıklığa kavuşturduktan sonra ulaşım. Bu iki sözcük, gerek Ingilizce ile Fransızca, gerek Türkçe sözlüklerde çok deģişik biçimlerde açıklanıyor, bu karışıklık hekimlik terimleri sözlüklerine de bir ölçüde yansımı̧ bulunuyordu.

Yunancada "nyx- nyktos, gece + alaos, kör + ops, opos, göz" sözcüklerinden oluşan nyktalops sözcügü hem gece hem de gündüz körlüğ̈̈ olan kişi anlamına gelmektedir. Kökendeki bu iki anlamlıı̆̆ın yukarıda sözü edilen karışıklıkların da kaynağı olduğunu sanıyorum. Bu. sözcük aynı yazılışla Látinceye geçmiş, Fransızcadaki "nyctalopie" ile Ingilizcedeki "nyctalopia" sơzcüklerine de kaynaklık etmiştir. Ingilizce büyük Webster sözlügünde sözccügün hekimlikıcki ilk anlamı "güçlü bir ışık alında ya da aydınlık günlerde iyi görüp geceleri, az. ışıkta ya da kapalı günlerde iyi görememe biçimindeki göz rahatsızlığı" olarak verilmekte, daha sonra da sözcügün karıştırılarak "hemeralopia" anlamında kullanıldığ belirtilmektedir.

Fransızca sözlüklerde -bu arada Robert'le Larousse'ta- ise bu iki sözcüge tümüyle tersi bir anlam verilerek "nyctalopie "ye "günđưüzkörlügü," "héméralopie"ye "gecekörlügü" denmektedir. Tahsin Saraç'ın Fransızca-Türkçe Büyük Sözlük'ünde de bu karşılıklar verilmektedir. Dr. Şefik lbrahim Iş̧̧il'le Ali Ulvi Elöve'nin TDK'ca yayımlanan Türkçe Hekimlik Terimleri Üzerinde Bir Deneme adlı sözliuğünde de "nyctalopie"nin Türkçesi "gündüz körlügü, gün körlük" (Osmanlıcası "amy-i ncharî") olarak verilmiştir. Bu sözlükte terimin Almancasının "Tagblindheit" olarak verilmiş bulunmasından, Almancada da durumun Fransızcadaki gibi olduğu sonucu çıkmaktadır. Dr. Sürèyya Ülker Tıp Terimleri Sözlüğünde "nyctalopie" için !. karağı, eşanlamlı sözcü̈kler olarak da gece sokurluğu, tavukkarası, tüngörmezlik, 2. hemeralopia karşılıkları verilmiştir. Ingilizce hekimlik terimícri sözlüklerinde "nyctalopia"nın karşısında ayrıca eşanlamlı karşılık olarak "nightblindness" (gecckörlüğ̈ü) sözcüğ̈une de yer verilmekıcdir.

Bu görme rahatsızlığ için halk ağzında tavukkarası sözcügünün kullanılmakta olması ögreticidir. Bilindiği gibi, tavuklar, ortalık kararmaya başlayınca, daha gece olmadan çevreyi görmemeye başlayıp kümesicrine yönelirler. Bu bakımdan gecekörlügü sözü yanılıcı olup "niktalopi"nin belki de en iyi karşılıgı "tavukkarası"dır. Gerçekten de, gece ya da koyu karanlıkta kimse göremez. Buradaki rahatsızlığın özelliği, kişinin "az ışıkta" iyi görememesidir. Işıe "az ışık görmezliği" karşılığını bu düşünceden yola çıkarak türcıtim.

Öyle sanıyorum ki, dilimizdeki karışıklık, Türkçcye önce Fransızcadan "nyctalopie," daha sonraları da Ingilizceden "nyctalopia" sözcügünün girmiş olmasından kaynaklanmaktadır. Yabancı dillerdeki sözcükleri dilimize olduğgu gibi alınca oradaki karışıklıkları da kaçınılmaz bir biçimde dilimize aktarmış olmakıayız. "Az ışık görmezliği" dendiginde anlam, hiçbir karışıklığa ya da belirsizliğe yol açmadan, an duru bir Türkçe ile anlatılmıs olmaktadır.

Bu duruma göre Fransizca ile Ingilizce'deki nyctalope (okunuşu: niktalop) sözcügünün karşılıł̆ da az ışık görmezi olacaktır. Böylece bir hekimlik teriminde gözü görmeyenlerin tepkiylc karşıladıkları Farsça kökenli "kör" sözcügünün kullanılmasından da kaçınılınış olmakıadır. 
2 Nisan 1987 Perşembe günü yukarıdaki açıklamaları kendisine okuduguum Ankara Üniversitesi Tıp Fakültesi Göz. Hastalıkları Anabilim Dalı Başkanı Prof. Dr. Sabahat Abadan, "niktalopi - hemeralopi". ikilisi için önerdiğim "az ışık görmezliłgi - bol ışık görmezliği" karşılıklanını çok başarılı bulduğunu, beğenip benimsediğini sőyledi.

\section{SCOREBOÁRD - SAYI GÖSTERGESI}

Ingilizce score adı, çeşitli anlamları arasında, bir spor karşılaşmasında tarafların sayı dutumu, kaça kaç oduklan anlamına gelir. Board ise, yine çeşitli anlamlanı arasında tahta demektir. Bu iki sözcükten oluşan scoreboard (okunuşu: skorbord) bileşik sözcụ̈ü, spor karşılaşmalarında yarışdaş takımların sayı durumlarını gösteren tahı ya da levhalar, günümüzde de daha çok ışıkla çalışan göstergclerdir. Scoreboard sơzcügüu genellikle göreç (tv) ya da yayaçta (radyo) bu karşılaşmaları veren spor konuşmanlarınca kullanılmakta, yazılı olarak kullanıldığında da sözcük Ingilizcedeki gibi yazılmaktadır. Sözcüge, gerck anlam, gerek işlev özelliğini göz önünde bulundurarak sayı göstergesi karşılığını öneriyoruz.

Örnek: Sepettopu oyunu alanlarındaki sayı göstergelerinde yalnız takımların yapıkları sayılar degil, karşılaşmanın hangi dakikasında bulunulduğu, oyuncuların yapukları el kesme gibi kural dışı davranışların sayısı da yer alır.

\section{SENARYO - GELIŞKI \\ SENARIST - GELIŞKI YAZARI, GELIŞKICI}

Italyanca scenario sözcügü o dildcki scena (sahne) sözcügünden türemiştir. Oradan Fransızca ile Ingilizceye geçen bu sözcük bu dillerden aynı senaryo söylenişiyle Türkçeye de geçerek yaygınlık kazanmıştır. Türkçe Sözlük, senaryonun tanımını "bir tiyatro ya da sinema yapıtının sahnelerini ve akışını gösteren yazılı metin olarak vermektedir. Sözcügün Ingilizcedcki ikinci bir anlamı "bir sinema filminin sahne sahne bütün gelişmeleriyle oyunun nasıl oynanacağının ayrınularını veren tasarımı, bir sinema oyununun tüm konusu"dur. Sözcük, anłam genişlemesi yoluyla, bir olayla ya da ülkeyle ilgili olası gelişmeleri gösteren lasarımlar ya da betimleyici yazılar anlamında da kullanılmaktadır. Sözcük dilimizde bu iki anlamda kullanım alanı bulmuştur. Bu sözcü̈ün batı dillerinde bir türevi olan senarist sözcügü de dilimize geçmiştir. Senaryo sözcügü için, sahnedeki ya da perdedeki bir oyunun bütün gelişme aşamalarını gösteren bir metin olması düşüncesinden yola çıkılarak, "çelişki" sözcügünün de yapısı örneksenerek, "gelişmek" cyleminden gelişki karşılığı türetilmektedir. Senarist için de gelişki yazarı, gelişkici karşılıkları öncrilmcktedir.

Örnek: Bir tiyatro oyununun gelişkisi özct bir metin görünümündedir. Uluslararası ilişkilerin incelendiği bu kuruluşta sọzz konusu ilişkilerle ilgili olarak oluşturulan çeşitli gelişkiler taruşılıyor. Bu filmin gelişki yazarı. (geliskkicisi) seçkin bir yazardır.

\section{SEXUAL HARASSMENT - SARKINTILIK; EŞEYSEL TEDIRGINLIK}

Ingilizcede to harass eylemi, "yormak, bizar ctmek, rahat vermemek" anlamına gelir. Bu eylemden türeyen harassment (okunuşu: herısmınt) adı "sıkıntı, rahatsızlık" demektir. Sexual'ın Türkçe karşılığ "ç̧cysel"dir. Sexual harassment, bir kimsenin, özcllikle bir kadının, karşı eşeyden bir kimscce cşeyscl amaçla rahatsız edilmesi anlamına 
gelir. Bu rahatsız edici davranışlar, bakma, söz dokundurma gibi biçimlerde olabileceği gibi, kişiyi eşeysel bir cylem konusu yapmak, bu arada elle rahatsiz etmek, en aşın durumlarda zorla eşeysel ilişkide bulunmak biçiminde olabilir. Bu konu, özellikle 1990'lı yıllarda Birleşik Amerika'da basın-yayın araçlarında tartışma konusu yapıldıktan sonra dünya çapında ilgi uyandırmış, bu arada ülkemizde de üzerinde durulmaya başlamışur. Kavramın dilimizdeki dogal karşılı̆̆ı sarkıntılık'ur. Kimilerinin doğru olarak kullandıklan bu karşılığın yanı sıra, kimi kez basında "cinsel taciz" karşılığının da kullanıldığı görü̈lmektedir. Arapça "cins"in sonuna Türkçe önad eki getirilerek Türkçe sözcük türetilemeyecełgi gibi tümüyle Arapça olan "taciz" sözcüğü de Türkçe olarak benimsenemez. Biz bu tür eylemlere konu olan kişinin içinde bulundugu durumu anlatmak üzere eşeysel tedirginlik karşılığını öneriyor, kavramı karşılamak üzere kural olarak sarkıntılık'ı benimsiyoruz.

Önek: 1992 yılında Amerikan basınında Deniz Gücü'ndcki kadın görevlilere yönelen sarkıntılık olaylarının ileri boyutlarda olduğgunu gösteren yayınlar yapılmıştır. Türkiye'de kadınların sarkıntılık korkusuyla gündüz bile kent içinde tek başlanna rahatça dolaşamamaları, eşeysel tedirginliğin yoğun bir olay olduğunu göstermektedir.

\section{SIT, SIT ALANI - KORUMA ALANI}

Latince situs (durum) sözcü̈gü sito biçimiyle Italyancaya geçmiş, o da daha sonra Fransızca site (okunuşu: sit) sözcüğüne kaynaklık etmiştir. Genel dildcki anlamı "güzel görünüm" (manzara) olan site sözcügünün kentbilimi ile ülke düzenlemesindeki anlamı "korunması gereken yer"dir. Sözcük bu anlamıyla, oradaki sit okunuşuyla Türkçeye de geçerek yaygın bir kullanım alanı bulmuştur. Sözcük uygulamada "sit" ya da "sit alanı" biçiminde kullanılmaktadır. Bu bağlamda sit, en geniş anlamıyla "ozellikli alan" demektir. Birçok yasalanmızda da yer alan sit kavramı, ulusal gezilikler (parklar), doga gezilikıcri, doğa anıtları, yaban yaşamı barınağı, güzel görünümlü alanlar gibi doğal nitelikte olabilecȩ̧̧ gibi, eski evler, ören yerler gibi çağbilimsel (tarihi) değer taşıyan alanlar da olabilir. Bu özelliktcki alanlar, söz konusu ozelliklerinin bozulmaması için koruma alına alınmakıa, yapı deģişiklikleri ya da kirletilme gibi bozucu etkilere karşı kamu kesimince güvencelenmektedirler. Sözcüğe, işlev özelliği göz önünde bulundurularak koruma alanı karşılığ önerilmekıedir. "Alan" anlamı sit sözcüğü içinde saklı bulunduğuna göre "sit alanı" biçimindeki kullanımın bir çeşit gereksiz yineleme niteliği taşıdığına burada de ğinmekte yarar vardır.

Örnek: Side kenti çağbilimsel bir koruma alanıdır.

\section{SOFISTIKE - INCELIKLI; YAŞAMI TANIMIŞ, GÜNGÖRMÜŞ}

Ingilizce sōphisticated (okunuşu: sofistikeytid) sözcügü, okunuşu Fransızcalaştırılarak sofistike (sophistiqué) söylenişiyle dilimize de bir ölçüde geçmiş, son günlerde bir görȩ tamıtımında bu biçimiyle sık sık kullanıldığı görülmüşı̈r. Yunanca sophos (akillı, bilgece) kökünden kaynaklanan bu sözcügün Fransızcadaki yaygın anlamı, katkı maddesi eklenmiş, taģşis edilmiş; doğallıktan uzaklaşmış, yapmacıklı; karmaşık'ır. Sözcük Ingilizcede de ilk sadeliģini yitirmiş, yapmacıklı anlamına da gelmckle birlikı daha dar anlamda çok karmaşık, incelikli gibi anlamlara gelmektedir. Sözcük kişiler için kullanıldıł̆ında birçok deneyimler, düşkırıklıklan yaşama sonucu akıllı, özcllikle dünya işlerinde akıllh, bilgece duruma gelmiş anlamını vermektedir. Sözcük dilimizde daha çok bu anlamda kullanılmaktadır. Bu anlamda 
sofistike bir kimse için Türkçede kullanılması gereken sözcükler yaşamı tanımış, güngörmüs, dahası -biraz abairtılı olmakla birlikte- feleğin çemberinden geçmiş'tir. Çeşitli yaşam deneyleri geçirmiş olmanın özcllikle vurgulanmak istendið̣̌i durumlar dışındaki genel kullanımında sözcüge Türkşede kullanılması gereken karşılık incelikli'dir. Inceliklilik, yaşamı çeşitli deneyimlerle tanımış olmanın bir sonucu olarak da algılanabilir. Bu bakımdan olumlu bir kişilik nitclemesi olarak sofistike'nin Türkçedeki karşııı̆ı̆ kanımızca "incelikli" olmalıdır.

Ornek: Bu kadının bütün davranışlarından incelikli (yaşamı tanımıs. güngörmüs) bir kişi olduğu açıkca anlaşılıyor.

\section{SURROGATE MOTHER - TAŞYIYICI ANÁ}

Ingilizcede "surrogate mother" sözünde geçen "surrogate" sözcügüu için Türkçe bir karşılık bulma gerełgini, Time dergisinin 23 Mart 1987 sayısinda "Technology and the Womb" başlıklı yazıyı okurken, 25 Mart 1987 Salı gecesi duydum. Yazıda, bizde "tüp bebek" olarak adlandırılan uygulama ile döllenmiş yumurtanın annenin ya da "surrogate" sözcügưule anlatılan bir başka kadının dölyatağında büyütülmesi yoluyla çocuk edinme uygulamasına Katolik kilisesinin karşı çıkıı̆ı belirtiliyordu. Papa John Paul II'nin de desteğini arkasına alan Vatikan, bir çocuğun "sağlıkbilimsel ya da dirimbilimsel yöntemlerle yapılacak bir müdahalenin ürünü olarak istenip düşünülmemesi gercktiğini," böylece "çocuğun bir çeşit uygulayımbilim nesnesi durumuna düşürülmüş olacağını" söylüyor, Batı Almanya Kardinali Ratzinger "uygulayım bakımından olanaklı bir nesnenin aktörel yönden onanabilir olmayabileceğinden" söz ediyordu. Konu özetle şuydu: Olağan yoldan çocuk yapamayan çiftler vardı. Kadının hckimlikte "Fallop kanalları" denen, benim Türçede "yumurta yolu" denmesini daha yerinde bulduğum, atmığın yumurtayı döllemek için geçip daha sonra döllenmiş yumurtanın dölyatağına inmek üzcre izlediği sał̆lı sollu iki yol ukalı olduğunda kadının yumurtası amcliyatla alını tüp içinde erkeğ in atmığıyla döllendikten sonra kadının dölyatağına yerleştirilcbilir, bu yapay döllenme için eşler dışındaki üçüncü bir kişinin atmığıyla yumurtasından da yararlanılabilirdi. Kadının sağlık durumu elverişli deģilse yada başka bir nedenle öyle uygun görülüyorsa tüpte đöllenen yumurta bir sürc sonra gelişip büyümck üzere bir başka kadının dölyatağına konabilirdi. Bugün dünyada bu yolla döllenmiş yaklaşık 1990 bebek vardır. Iş̧e annenin yerini alan bu kadına "surrogate mother" deniyordu. Latince surrogatus, surrogare, subrogare" (ikame etmck, yerine koymak) cyleminden kaynaklanan "surrogate" sözcügü "vckil, dclcgc, naip" gibi anlamlara geliyordu. 26 Mart 1987 Çarşamba sabahı bu konuyu kendisine açıp hangi Türkçe karşılığı kullanmanın uygun olacał̆ını sorduğum eşim, "taşıyıcı, taşıyıcı anne" karşııı̆ııı önerdi. Karşılık güzel, anlamı da çok iyi yansıtacak nitelikıeydi. Gerçekten de, yapılan iş bebeği dokuz ay süreyle karında taşımaktan başka bir şey deł̣ildi.

O gün öğle yemeğinden sonra Siyasal Bilgiler Fakültesinin gazcte odasında konuyu arkadaşıara açıp nitcliģini aydınlatıcı açıklamada bulunduktan sonra "surrogate" sözcügüne nasıl bir karşıllk bulunması gercktiğini sordum. Orada bulunan meslckdaşlardan Hüseyin Pazarcı'nın ağzından "taşıyıcı" sözü çıkınca sevinip akıl için yolun bir olduğunu söyledim.

Bu sözcüğğn öyküsünü yazdığım 27 Mart 1987 günü durumu bir de konunun gerçek bir uzmanıyla görüşmüş olmak için Ankara Dogumevi Başhckimi Dr. Ziya Durmuş'u telefonla aradım. Ü̧̧ çocuğumuz da bu Doğumevinde dünyaya geldił̧i için aramızda bir 
yakınlık bulunan Dr. Durmuş, eşimi, çocukları sordu. Bu arada gozzümün takvim yaprağına ilişmesi üzerine bugünün tıp ögrenimi yapmakta olan en büyük ợlumuzun doğum günü olduğunu, yirmi bir yaşını doldurduğunu söylediğimde ikimiz birden yıllann ne çabuk akıp gittiği gerçeğini dile getirmekten kendimizi alamadık. Sonra "surrogate mother"a ne dediklerini sordum. "Kiralık anne" karşılığını verdi. Bu iş uygulamada genellikle bir "kira" karşılığında yapılsa da durumun hep böyle olmayabileceğini, orneğin dölyatağında bir sakatlık bulunan ya da sağı̆ğ gebeliğe elverişli olmayan bir kadının kızkardeşinin bu görevi bir çıkar karşılığı olmadan da yerine getirebileceğini sőylemem üzerine bu görüşe katılan Dr. Durmuş, görüşme surasında "taşıyıcı anne" sözünü birkaç kez kullandı. Bu arada karı-kocanın eşey gózelerinden yararlanılarak ortaya konacak bir tüp bebeğin annenin dölyatağında büyütülmesi dışındaki uygulamalara, bir başka deyişle aralarında evlilik bağı bulunmayanların eşey gözelerinden üretilerek ya da anneden başkasının doblyată̆ında büyütülerek çocuk yapmaya, ülkemiz ortamının şimdilik elverişli olmadığını söyledi. Görüşme sırasında "taşıyıcı anne" sözünü birkaç kez çok akıcı bir biçimde kullanmış olmasını bu karşılığı benimsemiş olduğunun bir kanıı olarak alıp alamıyacağımı sormam üzerine Dr. Durmus bundan sonra bu sözcügü kullanacağı karşılı̆̆ını verdi.

O surada odamda bulunan Ibrahim Kaplan'ın Adalet Bakanlığı Hukuk Işleri Genel Müdürlügünde görevli Dr. Turgay Yücel'in de bu konuyla ilgilendiğini söylemesi üzerine onunla da ilişki kurup görüştük. Yücel, kendisinin basında karşılaşı̆ğ "taşıyıcı anne" sözünü kullandığın, Fransızcada bu uygulamaya "le prêt d'utérus" (dölyatağı kiralama), "surrogate mother"a "la mère de substitution, la mère porteuse" (ikame anne, taşıyıcı anne), "surrogate motherhood"a "la matemité pour autrui" (başkası için annelik) dendiğini söyledi. Yücel'in ayrıca böyle bir sözleşmenin Türk hukukunda olduğu gibi Fransız hukukunda da geçerli olamayacağını söylemesi üzerine, bugünlerde Birleşik Amerika' da bir taşıyıcı anneyle eşinin bu yoldan edinilen bir bebeģi eşey gözeleri kullanılan ana babaya vermck istememeleri üzcrine açılan davada karar aşamasına gelinmiş olduğunu bclirttim. Karşılıkla ilgili olarak burada da akıl için yolun bir oldugu anlaşılıyordu. Yazılarında "laşıyıcı anne" sözünü kullanıp kullanmadığını sorduğum Turgay Yücel, Sağlık Bakanlığına yolladığı bir raporda kullandığını söyledi.

Bu durum karşısında surrogate için taşıyıcı, surrogate mother için taşıyıcı anne ya da ana karşılığını kullanmak en doğru çözüm olarak görünmektedir.

\section{SÜPER - OLAĞANÜSTÜ}

Ingilizce, Fransızca gibi batı dillerinde kullanılan super öneki Latinceden alınmıştır. Bu önek, başına geldiģi sözcüklere "üst, üstünde, çok fazla" anlamlarını katar. Süpersonik, hızı ses hızının üstünde' olan, saglıkbilimde süperalimantasyon fazla beslenme, süpermaksilla üst f̧cne anlamına gelir. Süpcrmarket ise, besin maddeleri ile onlarla yakından ilgili toz sabun, fırça gibi temizlik gereçlerinin satildığı belirli bir oylumun üstündeki "büyük besin satımevi" demektir. Sözcük, önad (sıfat) olarak da daha çok argoda "çok iyi, mükemmel, birinci sınıf" anlamına gelmektedir. Sözcük 1990'lı yıllann başında ơzel göreçle (tv) yayaçların (radyo) ülkemizde yaygınlaşmasından sonra ortaya çıkan aşırı bir Ingilizce özentisinin etkisiyle özcllikle bu son anlamda yaygın bir kullanım alanı bulmuş, yerli yersiz kullanılmaya başlanmıştır. Süper sözcügü daha çok "süper ơdül, süper araba" gibi anlatımlar içinde kullanılmakıadır. Sözcügün değinilen önad anlamı için, dilimizde onu en iyi yansıltığını düşündügümüz olağanüstü karşılığını öneriyoruz. 
Örnek: Bu genç her anlamda olağanüstü bir ögrencidir. Bu yarışmaya katılanlara olağanüstü ödüller veriyoruz.

\section{TALK SHOW - SÖZLÜ GÖSTERI}

Ingilizce talk (konuşma) ile show (gösteri, ełglence gösterisi) ögelerinden oluşan talk show (okunuşu: tok şov) sözcü̈̆ü ülkemizde özel görecin (tv) ortaya çıkıp yaygınlık kazanmaya başlamasından sonra, 1990'lı yılların başlarında, o dildeki yazılışıyla, söylenişiyle, oldugu gibi kullanılmaya başlamıştır. Talk show, kişilerin özellikle de ünlü kişilerin konuşmalara, tartışmalara katıldığı ya da onlarla görüşmeler yapılan yayaç (radyo), göreç izlencelerine verilen addır. Daha çok bir söyleşi görüntüsü ta̧̧ıyan bu tür izlenceler dinleyici ya da izleyicilerin ilgisini çckmek, onları eglendirmek, biraz da bilgilendirmek amacını güdcrler. Talk show sözcügüne, gerck anlam gerek işlev özellił̌i göz önünde bulundurularak, söz ağılıklı olmasının yanı sıra gösteri niteliğini de dogal olarak vurgulayan sözlü gösteri karşılığı öncrilmekıdir. Talk show host karşılıgı olarak da sözlü gösteri yöneticisi önerilmekıcdir.

Örnek: Sözlü gösterilere daha çok ünlü ses, sahne, perde sanatçlları katılıyorlar.

\section{TOP 10 - EN ÇOK SEVILEN ON ŞARKI DORUKTAKI 10, TEPEDEKI 10}

"Top 10," ülkemizdeki örel bir göreç yayınında hafıanın en çok sevilen 10 şarkısının belirlendiği bir izlencenin adıdır. "Top" sözcügünün Türkçedeki içi lastik ya da hava dolu yuvarlak nesne anlamındaki "top"la hiçbir ilişkisi yoktur. Ingilizcede "top" (okunuşu: tap) "tepe, doruk, en yüksck düzcy" gibi anlamlara gelen bir sözcüktür. Buradaki anlamı "en çok sevilen 10 şarkı" (tunes) ya da "doruktaki, tepedeki 10"dur. Körükörüne bir Amerikan öykünmecilig̣inden kaynaklanan bu söz için anılan karşılıklar önerilmektedir.

Örnek: Son ayın en çok sevilen (dorukıaki, tepedeki) 10 şarkısı soruşturmasının sonuçlarını sunuyoruz.

\section{VAV - VAY CANINA, VAY}

Ingilizce wow (okunuşu: vav) sözcügü, güçlü bir beğenme ya da şaşırma duygusunu anlatan bir ünlemdir. Sözcügün ad olarak bir anlamı da "çarpıcı başarı"dır. Türkiye'de özel görcç (เv) yayınlarının yaygınlaşı̆ı̆ 1992 yılında, bilinçsiz bir Amerikan öykünmeciliği furyası içinde, tanıtım izlenceleri yoluyla dilimize de sokulmaya çalışılan bu sözcük aslında tümüyle gercksizdir. Tanıtımlarda bir malın duyurusu yapıldıktan sonra gençlerden oluşan bir küme "vavvv!" diyc bağırtılmakı, böylece ürünün üstün niteliği karşısındaki şaşkınlıkları dile getirilmek istenmekıcdir. Bu gibi durumlarda vav sözcügünün dilimizdcki doğal karşılığı olan, sözcügün anlam ile işlev özelliklerine de uygun düşen vay canına, vay sözcüklerinin kullanılmasını ỏneriyoruz.

Örnek: Üniversite ögrenci adayları! Bu kılavuz sınavda başarınızın vazgeçilmez ön koşuludur. Vay canına! (Vayyy!) 